\title{
UMA MODALIDADE ARQUITETÔNICA PRIMITIVA E AUTÊNTICA*
}

Lenora Barbo

Andrey Rosenthal Schlee

\section{Resumo}

A construção da Nova Capital se deparou com um conjunto de formas de ocupação territorial que podemos chamar de tradicional no que se refere aos modos de viver, bem como aos de produção de subsistência, onde os antigos moradores tinham a pecuária de pequeno porte como sua principal atividade econômica. Para compreender as residências rurais das antigas fazendas, pesquisamos a arquitetura civil de Goiás e realizamos um inventário de dez moradas rurais encontradas nos limites do atual Distrito Federal que, tudo indica, remontam ao século XIX. Estudou-se, particularmente, as formas de implantação das edificações, suas técnicas construtivas e o agenciamento

* Versão ampliada de trabalho apresentado no $13^{\circ}$ Seminário História da Cidade e do Urbanismo, 2014. espacial do corpo da residência. Assim, o artigo explora uma modalidade arquitetônica que, segundo Lucio Costa, era "primitiva e autêntica" e que antecedeu às formas de ocupação territorial e de viver propostas, ou impostas, pelo pensamento modernista.

Palavras-Chave: Goiás, Distrito Federal, Brasília, arquitetura rural. 


\section{A ARQUITETURA REGIONAL AUTÊNTICA}

Esse artigo sobre a arquitetura rural do século XIX erguida na área de influência do atual Distrito Federal (DF) se inicia, intencionalmente, com extratos de textos de duas figuras-chave para a execução da nova capital: o próprio autor do Plano Piloto de Brasília e o engenheiro-calculista dos principais palácios da cidade. Foram dois intelectuais comprometidos com a escrita de uma história da arquitetura nacional que, simultaneamente, buscava valorizar e preservar parte do passado colonial e construir e consolidar uma linguagem modernista. História onde Aleijadinho e Niemeyer, Diamantina e Brasília receberam lugar de destaque. Costa e Cardozo estudaram a arquitetura brasileira. Buscaram compreendê-la com olhos de quem queria vê-la. Ambos colaboraram com o Serviço do Patrimônio Histórico e Artístico Nacional-SPHAN, e constataram a particular desatenção com a arquitetura do mundo rural.

A nossa antiga arquitetura ainda não foi convenientemente estudada. (...) A arquitetura regional autêntica tem as suas raízes na terra; é produto espontâneo das necessidades e conveniências da economia e do meio físico e social e se desenvolve, com tecnologia a um tempo incipiente e apurada, à feição da índole e do engenho de cada povo; ao passo que aqui a arquitetura veio já pronta e, embora beneficiada pela experiência anterior africana $\mathrm{e}$ oriental do colonizador, teve que ser adaptada como roupa feita, ou de meia confecção, ao corpo da nova terra. À vista desta constatação fundamental, importa pois conhecer, antes de mais nada, a arquitetura regional portuguesa no próprio berço, porque é na construção popular de aspecto viril e meio rude, mas acolhedor, das suas aldeias que as qualidades da raça se mostram melhor, percebendo-se, desde logo, no acerto das proporções e na ausência de artifícios, uma saúde plástica perfeita, se é que se pode dizer assim (COSTA, 2018).

A rigor, não foi ainda realizado o inventário das propriedades rurais brasileiras, e o seu levantamento tem sido conseguido de meras circunstâncias ocasionais, sem obedecer a qualquer plano de estudo ou pesquisa (CARDOZO, 2009).

Em 1964, Costa cobrou providências para o tombamento da Fazenda Babilônia (GO):

Não se compreende que, morando em Brasília há tanto tempo, o Alcides [da Rocha Miranda ${ }^{1}$ ] que é tão sensível a essa modalidade arquitetônica primitiva e autêntica, já não houvesse ele próprio tomado a iniciativa, e que os demais responsáveis pela faculdade na UNB não se tenham utilizado desse exemplar tão acessível e significativo para trabalho de campo - levantamento, fotografias, reconstituição. Ou será que desconhecem? Se o caso é esse - é inconcebível (grifo nosso) (COSTA, 2004).

O tombamento da Babilônia ocorreu em 1965 e foi o primeiro a proteger uma construção rural na região 
Centro-Oeste do Brasil. Com valores históricos, artísticos e arquitetônicos indiscutíveis e de fácil constatação, a Fazenda Babilônia, provavelmente erguida entre 1800 e 1805 (JAYME, 1943), é uma exceção em todos os sentidos. Podendo-se afirmar que não apresenta os padrões que caracterizaram a arquitetura rural goiana do século XIX, conforme identificados por Adriana Oliveira (2010), por Lena Freitas e Nancy Silva (1995) e por Lenora Barbo (2010).

A localização geográfica de Goiás em relação ao litoral brasileiro resultou no estabelecimento de uma rede de antigas estradas coloniais e no desenvolvimento, especialmente no mundo rural, de um modo de vida particular, com a adoção de soluções para os problemas que lhes eram próprios.

No Centro-Oeste, e em Goiás em particular, inexistiu a agricultura de exportação, tal como praticada no Nordeste e no Sudeste. Com poucas exceções que confirmam a regra geral, predominaram, durante as primeiras décadas de colonização, as pequenas propriedades rurais com meia légua em quadra, localizadas próximo à boca das minas. (...) Plantando roças de subsistência nas quais se praticava o cultivo da mandioca e do milho (...) essas fazendas diferiam das plantations litorâneas não somente pela dimensão menor, como também pelo fato de serem trabalhadas por braços da própria família do proprietário, acrescidos eventualmente de um número limitados de escravos (...). A vida quotidiana era trabalhosa e árdua, despida de quaisquer veleidades de luxo e até mesmo de conforto. A moradia, o transporte, os utensílios domésticos revestiam-se de feição utilitária, sem preocupações estéticas (grifo nosso) (FREITAS; SILVA, 1995).

Quando da construção de Brasília, a região do atual DF apresentava uma baixíssima densidade populacional, correspondendo a um habitante por quilômetro quadrado em 1958 (IBGE, 1959), e estava dividida em grandes glebas rurais, as denominadas fazendas, originalmente pertencentes ao território de dois municípios goianos do século XVIII - Formosa (Couros) e Luziânia (Santa Luzia) - e um do século XIX Planaltina (Mestre d'Armas) (Figura 1). Região que apresentava dois núcleos urbanos já consolidados, o de Planaltina (1811) e o de Brazlândia (1933). Assim, quando da execução dos primeiros edifícios modernistas no Plano Piloto, o DF já contava com um acervo patrimonial representativo de momentos e contextos históricos anteriores, identificável ainda hoje nos setores tradicionais ou centrais dos núcleos citados, como a Igreja de São Sebastião (1880) ou a edificação que atualmente abriga o Museu Municipal (1898), ambos em Planaltina e de feição colonial. Arquitetura de matriz vernacular, encontrada também nos remanescentes de várias construções rurais, particularmente nas moradas de fazendas, onde os antigos proprietários mantinham a pecuária como a sua principal atividade econômica. 
Figura 1 - Codificação dos imóveis fundiários dos antigos municípios goianos. Fonte: BARBO, 2010.

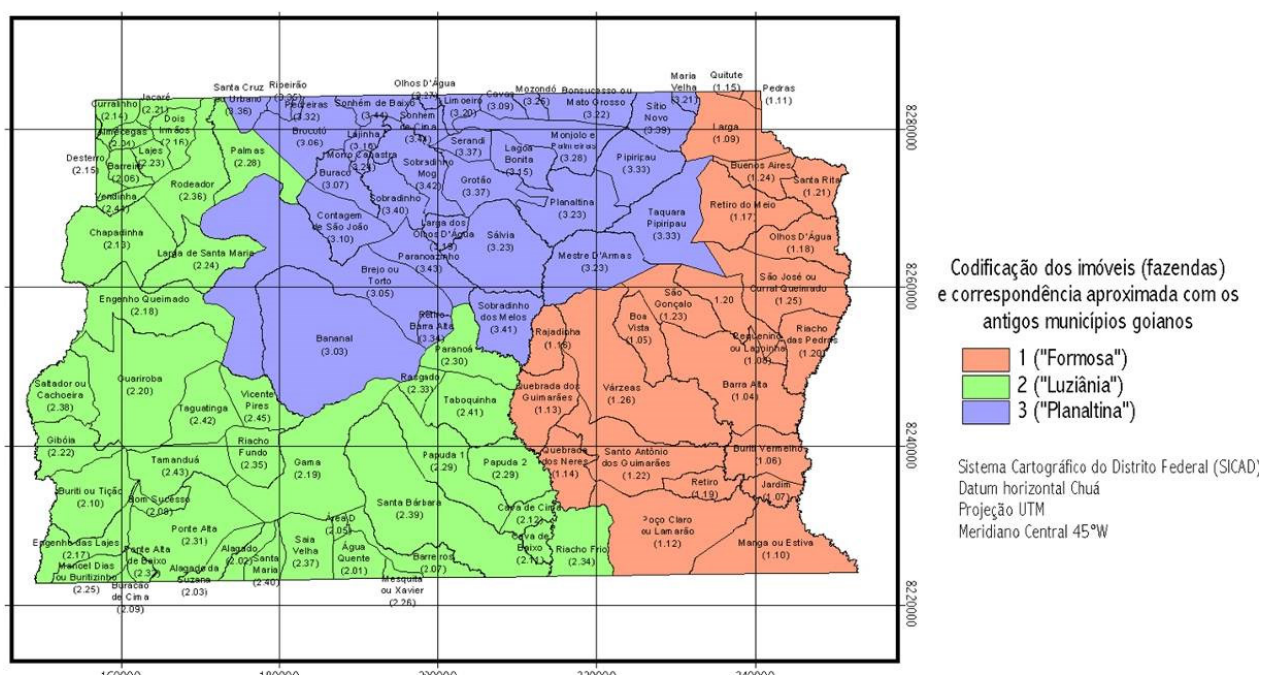

Segundo o Dicionário da Arquitetura Brasileira (CORONA; LEMOS, 2017), partido em arquitetura:

\section{é o nome que se dá à consequência formal de uma série de determinan- tes, tais como o programa do edifício, a conformação topográfica do terre- no, a orientação, o sistema estrutural adotado, as condições locais, a verba disponível, as codificações das postu- ras que regulamentam as construções e, principalmente, a intenção plástica do arquiteto.}

Para alguns dos principais estudiosos da arquitetura rural brasileira do período colonial, os mais diferentes condicionantes e/ou determinantes, geraram, em todo o Brasil, apenas dois partidos básicos: o partido fechado e o partido aberto. $\mathrm{O}$ primeiro é caracterizado por abrigar, reunir e ligar sob um mesmo teto, todos os elementos de um dado programa arquitetônico rural (coabitação de funções distintas); e o segundo, ao contrário, por hierarquizar, distribuir e afastar os vários elementos (coabitação de apenas funções semelhantes). Como exemplo de partido aberto temos os engenhos pernambucanos do açúcar, e de partido fechado, a própria sede da Fazenda Babilônia - acolhendo sob uma só cobertura a casa de morada, a capela, os quartos de hóspedes e o engenho de açúcar com suas inúmeras dependências.

No caso particular das antigas fazendas goianas atualmente localizadas no $\mathrm{DF}$, foi o partido aberto que se afirmou. Assim, temos uma edificação com função residencial - a morada - e uma série de outras pequenas construções destinadas a funções diversas ligadas à pecuária e a autossuficiência do lugar. Conjunto estrategicamente implantado nas proximidades de um rio, córrego ou rego d'água (também utilizados como fonte de energia) e que interage com um terreiro e um pomar. 
As soluções construtivas também eram resultado de uma busca natural de conforto ambiental, surgiram de forma espontânea e se acomodaram lentamente pela experiência acumulada:

\begin{abstract}
De modo geral, o predomínio dos cheios sobre os vãos; o tamanho das aberturas; a ausência de fechamentos transparentes e a espessura das grossas paredes de pedra, taipa e, mais tarde, tijolos de barro, garantiam às construções coloniais uma alta resistência térmica (propriedade do material em resistir à passagem do calor), maior inércia térmica (retenção de calor) e menor perda de calor interno. Efeitos ampliados ou reduzidos quando da existência ou não de forro e/ou piso nos compartimentos (SCHLEE, 2001).
\end{abstract}

A arquitetura civil produzida em Goiás ${ }^{2}$ pode ser considerada como uma das mais simples que se conhece dentro do panorama arquitetônico representativo do período colonial. Simplicidade sempre mais marcada no meio rural, onde aflorava em função do isolamento, dos modos de vida e do baixo poder aquisitivo dos moradores. São basicamente edificações de planta quadrada, elaboradas a partir de uma estrutura autônoma de madeira, comumente chamada de gaiola, com os vãos preenchidos por alvenaria de adobe ou pau- a-pique. Em estudo sobre as paisagens rurais do sudoeste goiano, o geógrafo Aziz Ab'Saber (apud BRUNO, 1959) observou que:
As sedes são casarões de um pavimento só e pouco imponentes, construídos de adobes entre armações de madeira e recobertos de telhas comuns - e caiados de branco. (...) o tipo dominante de construção nas fazendas regionais: após o corpo frontal do edifício, que se volta para a estrada, seguem-se prolongamentos laterais mais baixos, na forma de puxadinhos, com a estrutura das paredes de adobe barreado e caiado (grifo nosso).

As técnicas construtivas utilizadas em Goiás aproximavam-se daquelas produzidas nos primeiros momentos da arquitetura residencial de Minas Gerais, distanciando-se daquela usada em São Paulo pelos bandeirantes, que era, preferencialmente, a taipa de pilão.
A repetição da tipologia em todo território goiano, $o$ aprendizado pela prática da construção, a ausência qua- se absoluta de inovações essenciais na composição da forma construída e sua permanência através do tempo (quase dois séculos) são indicadores inconteste daquela que se denomina casa tradicional goiana (VAZ; ZÁ- RATE, 2003).

Em Goiás, o barro foi empregado na confecção de telhas; no revestimento como reboco; no piso de mezanela ${ }^{3}$ e nas paredes, compondo técnicas como, principalmente, o adobe e о pau-a-pique. $\mathrm{O}$ adobe é um paralelepípedo de barro de grandes dimensões, empregado como os tijolos, mas diferindo-se destes por não ser cozido ao forno. De barro cru, seco

\footnotetext{
${ }^{2}$ Minas de Goiás até 1749 , Capitania de Goiás de 1749 a 1822; Província de Goiás de 1822 a 1889 e Estado de Goiás a partir de 1889.

${ }^{3}$ Um tipo de ladrilho feito de barro queimado, à moda do tijolo, utilizado como revestimento de piso, característico da arquitetura originária do Oriente Médio (COELHO; VALVA, 2001).
} 
à sombra e, depois, ao sol, é composto de argila e areia, geralmente, misturadas com estrume e fibras vegetais. Já o pau-a-pique consiste na montagem de uma trama de madeira, com peças roliças colocadas na vertical, fixadas tanto aos baldrames quanto aos frechais ${ }^{4}$, formando um gradeado trancado que será preenchido com barro.

Para sua conservação, as paredes de terra crua requerem a adoção de proteção. Contra as chuvas, além dos beirais dos telhados, as paredes eram sempre recobertas por uma camada de reboco, composto de terra, areia e cal e, por cima, uma camada de pintura à base de cal. Para evitar a umidade proveniente do solo, a solução comumente adotada consistia na execução de embasamentos em pedra.

$\mathrm{Na}$ construção de nossa arquitetura tradicional, diversas foram as madeiras empregadas, assim como foi variado o seu uso. Roliças no encaibramento das coberturas ou na armação da trama do pau-a-pique; e lavradas na estrutura de sustentação das coberturas e paredes, nos barrotes de sustentação de pisos e nas peças de enquadramento dos vãos. $\mathrm{Na}$ forma de tabuado para pisos, forros e aberturas; treliçadas para a vedação de janelas ou, ainda, delicadamente trabalhadas na forma de cachorros (apoios) para os beirais.

\section{AS MORADAS RURAIS - INVENTÁRIO}

Em 1958, Altamiro Pacheco (1975), na condição de presidente da Comissão de Cooperação para a Mudança da Nova Capital, finalizou um importante relatório acerca das propriedades rurais goianas contidas no futuro território do DF. Entre outras coisas, relacionou os imóveis rurais então pertencentes aos três municípios-mães (Formosa, Planaltina e Luziânia) e que deveriam ser desapropriados. O levantamento foi consolidado no documento Novo Distrito Federal

- Planta-Índice Cadastral, elaborado a partir do lançamento dos limites (divisas) de todos os imóveis situados dentro do DF sobre folha cartográfica, na escala de 1:100.000 (Fig.2).

Além de demarcar o perímetro fundiário dos imóveis, o mapa assinalou as casas de fazenda então existentes (Fig. 3), assim como reproduziu toda a rede hídrica do território. Pela primeira vez, o projeto de Lucio Costa para o Plano Piloto teve o seu esboço lançado sobre as terras da fazenda Bananal, acrescido das penínsulas norte (implantada na fazenda Torto) e sul (implantada nas fazendas Gama, Papuda e Rasgado).

De posse de tal Planta-Índice Cadastral de 1958, em 2008, buscamos localizar e identificar quais as construções rurais sobreviveram à ação do tempo e do homem. Após pesquisa histórica e visitas de campo, foram encontrados $\mathbf{~ d e z}$ exemplares (Fig. 4) cujas características permitem supor serem edificações que 
remontam ao século XIX, quais sejam: morada da Fazenda Curralinho; Desterro; Gama; Monjolo I; Monjolo II; Saco Grande I; Saco Grande II; Sobradinho I; Sobradinho II; e Fazenda Velha. O inventário então realizado consistiu no levantamento arquitetônico da morada rural; no seu registro fotográfico; na identificação de suas características em relação à localização no espaço geográfico do DF, aos padrões arquitetônicos, aos materiais utilizados e aos sistemas construtivos empregados 5 .

Como particularidade, temos que, das dez moradas inventariadas, cinco foram selecionadas anteriormente como Patrimônio Vernáculo Rural pelo GT/ Brasília ${ }^{6}$ que, em estudos desenvolvidos na década de 80, destacou a importância da preservação de doze exemplares de arquitetura vernacular do centro-oeste localizados no território do DF. As cinco moradas rurais são: Casa da Fazenda Curralinho, na Região Administrativa de Brazlândia; Casa da Fazenda Gama, na Região Administrativa do Núcleo Bandeirante; Casa da Fazenda Monjolo, na Região Administrativa de Planaltina; Casa da Fazenda Saco Grande I (Fazenda Jardim), na Região Administrativa do Paranoá; e Casa da Fazenda Sobradinho I (Sobradinho), na Região Administrativa de mesmo nome.

Para Lemos (1989), em Portugal praticamente nunca existiu uma casa rural como a brasileira, isto é, uma residência absolutamente isolada num latifúndio, às vezes, distante léguas de outra morada ou de uma cidade ou vila. Lá, os minifúndios, de um modo ou de outro, agrupam-se em volta de pequenas aldeias. Na divisão territorial brasileira, as grandes distâncias resultavam no isolamento das famílias, que frequentavam as cidades distantes somente nos dias de festas muito importantes, poucas vezes ao ano.

As grandes distâncias e a precariedade dos caminhos transformaram a hospitalidade numa obrigação social, numa questão de sobrevivência. Não fugindo à regra, o quarto de hóspedes no corpo da casa de morada, os alojamentos para gente menos categorizada nos arredores das dependências de serviço. Daí os cercados para as mulas e cavalos dos passantes que pedissem pouso. Nem sempre a comida estava garantida, mas a cama e a rede estavam (LEMOS, 1989).

A rusticidade do ornamento dava o tom à vida de Goiás no século XIX. Rústico e pobre era também o homem que o produzia, transitando entre a fragilidade da vida urbana e a precariedade do mundo rural, a léguas de distância do resto do mundo. (...) As fontes documentais explicitam, com abundância, exemplos extremos dessa escassez (OLIVEIRA, 2001).

\footnotetext{
5 SCHLEE et al. Preservar e Intervir em Brasília. $O$ caso das antigas fazendas do Distrito Federal, 2009.

${ }^{6}$ O GT/Brasília, que atuou de 1981 até 1988 , foi criado pelo Instituto do Patrimônio Histórico e Artístico Nacional - IPHAN, então Secretaria do Patrimônio Histórico e Artístico Nacional - SPHAN/Fundação Pró-Memória, juntamente com o Governo do Distrito Federal e a Universidade de Brasília - UnB para estudar, propor e adotar medidas que visem a preservação do Patrimônio Histórico e Cultural de Brasília.
} 
Figura 2 - Mapa "Novo Distrito Federal Planta-Índice Cadastral" (FARIAS, 2006). Levantamento dos imóveis fundiários do DF em 1958, assinaladas as casas de fazenda em cada um deles. Área ampliada em destaque vermelho.

Figura 3 - Detalhe da localização das moradas rurais.

Figura 4 - Localização no território do DF das dez moradas rurais inventariadas. Fonte: BARBO, 2010
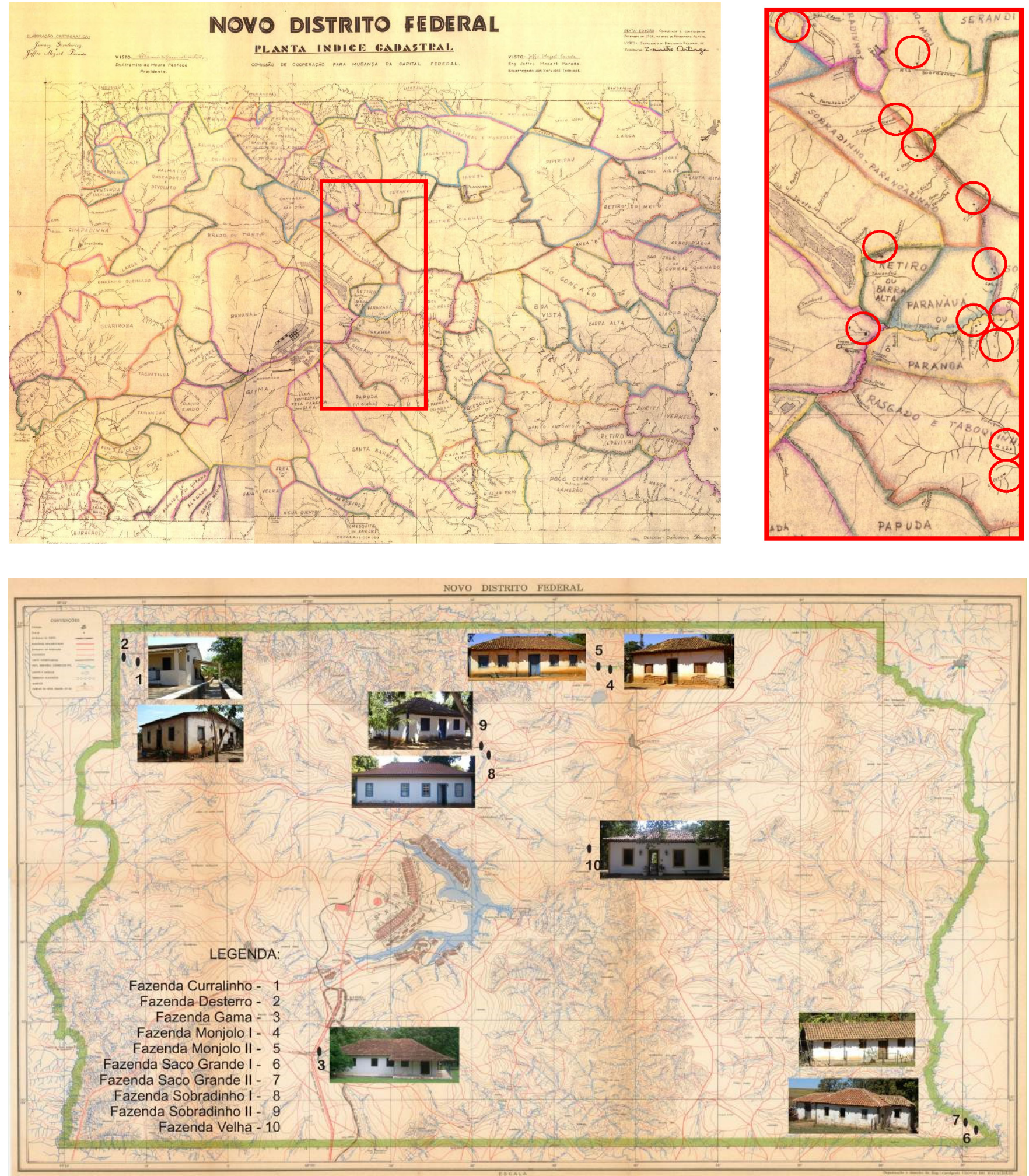


\section{DOIS EXEMPLOS DE MORADAS RURAIS}

Das propriedades rurais estudadas, no presente artigo, nos detivemos, especialmente, em duas: as moradas das Fazendas Sobradinho I e II, sobretudo em função da existência de outro importante documento cartográfico, a "Planta da Fazenda Sobradinho" registrada no Cartório de Registro de Imóveis de Brasilinha/GO, em 1928. Nesta Planta foi assinalada a localização de onze edificações, entre elas as moradas Sobradinho I e II. As duas edificações remanescentes se localizam em um vale, literalmente às margens da antiga "Estrada da Bahia", também conhecida por "Estrada de Cavalleiros à Torto" ou "Estrada Real à
Goyazes" (Figs. 5 e 6). As moradas estão localizadas na atual Região Administrativa de Sobradinho, distantes $200 \mathrm{~m}$ uma da outra, próximas ao córrego Brejo do Lobo. A região é irrigada por córregos e ribeirões que descem dos morros circundantes e o entorno é composto por diversas árvores frutíferas.

Sem dúvida, Sobradinho está entre os nomes mais antigos da toponímia dessa região. Em 1734, o tropeiro José Diogo registrou em diário manuscrito sua passagem por "Sobradinho" (DIOGO, 1734), nos limites do atual Distrito Federal. Graças ao seu relato, que cita nominalmente os pontos transpostos, podemos reconhecer hoje os sítios por onde andou, visto que muitos ainda conservam a mesma toponímia:

Roteiro das fazendas que há no caminho que vay do Rio de São Francisco p.a as Minas dos Goyazes athe o Arrayal de Meyaponte. (...)

Aquy nestas fazendas acabam as povoações antigas e principião as novas depois que se abriu o caminho para os Goyazes.

Do Faz tudo ao Ribeirão de São João 5 (Légoas)

Dahy a Santa Rosa 7

Dahy aos Bezerras 5

Aquy a estas fazendas em sahir mais três estradas, hua de São Romão pello Paracatu asima; outra da Barra do Rio das Velha; outra das Minas Geraes que busca o Abayté.

Dos Bezerras a Lagoa Fea 4

Dahy a Bandeyrinha

Dahy a João da Costa 4

Dahy ao Monteiro

Dahy ao Sobradinho 2

Dahy às Três barras 3

Dahy aos Macacos

Dahy ao Ribeirão da Área 7

Dahy ao Corumbá que não está povoado 5

Dahy ao Arrayal da Meyaponte (grifo nosso). (DIOGO, 1734). 


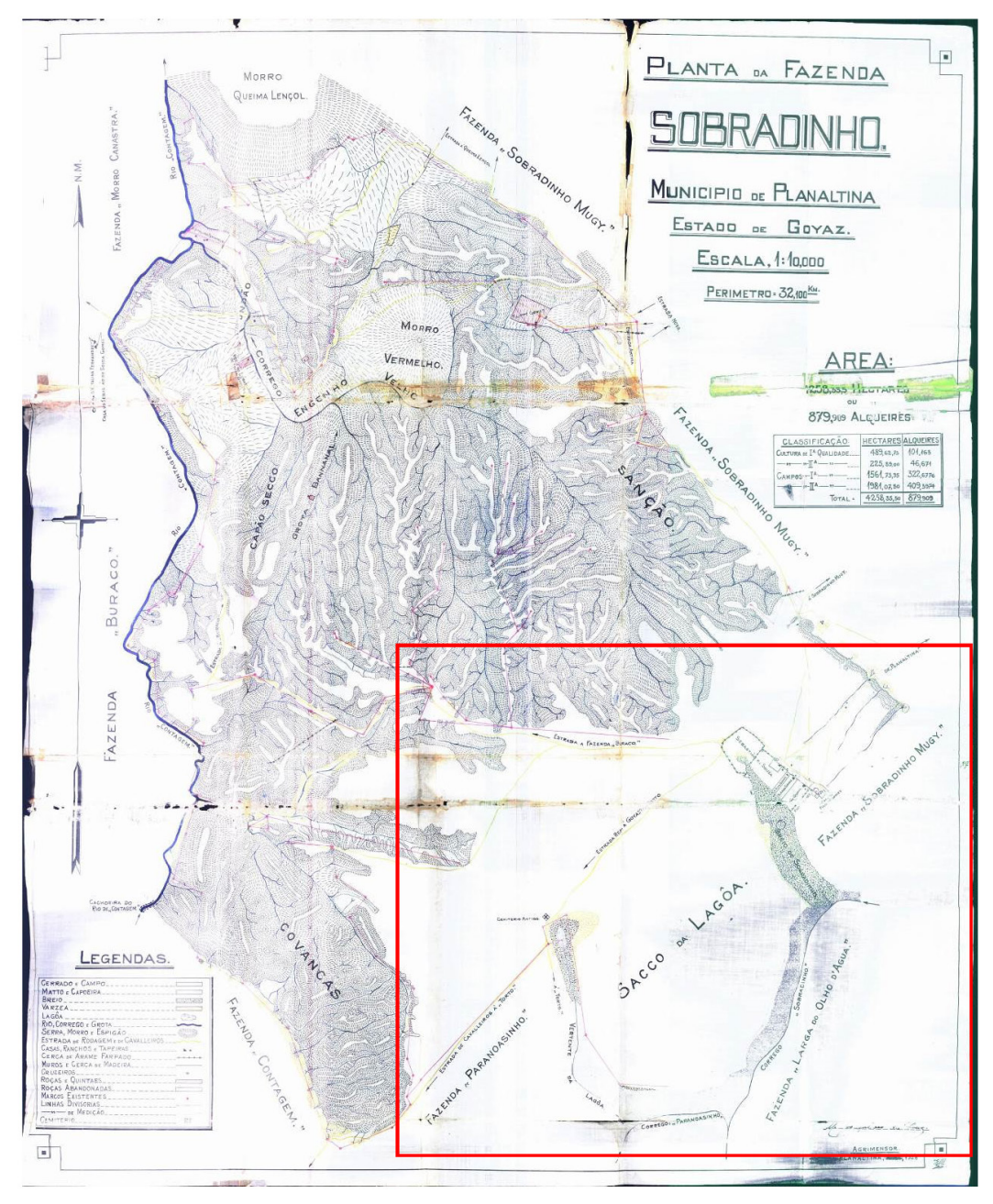

Figura 5 - Planta registrada da Fazenda Sobradinho. Área ampliada em destaque vermelho. Fonte: BARBO, 2010.

Figura 6 - Destaque 1 - "Estrada de Cavalleiros à Torto" assinalada no documento. Destaque 2 - "Estrada Real à Goyazes" assinalada no documento. Destaque $3-$ Localização de onze edificações, entre elas as moradas Sobradinho I e II, às margens da "Estrada Real à Goyazes". Fonte: BARBO, 2010.

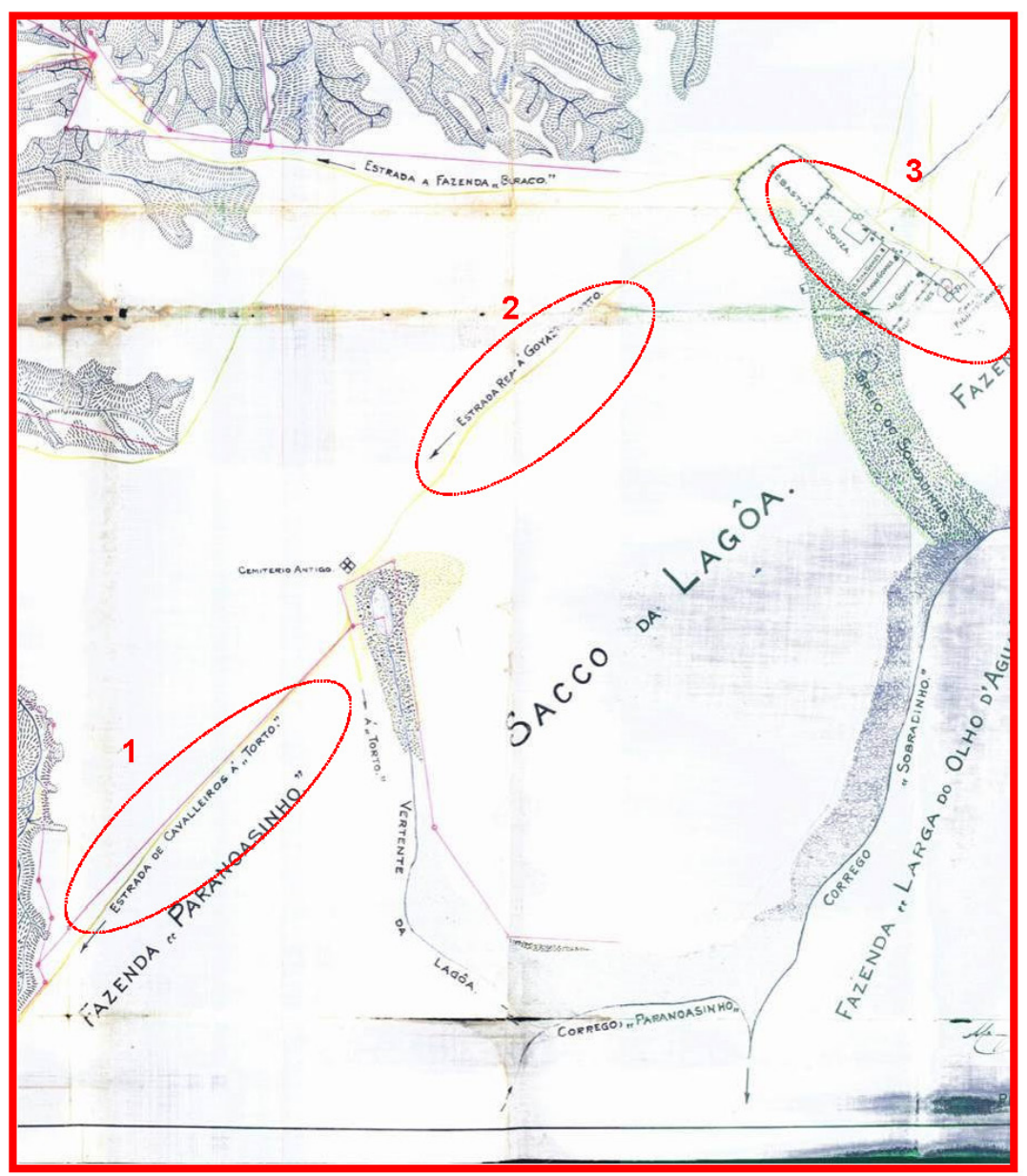


O tropeiro nos deixa a certeza que o território do atual Distrito Federal não era um deserto, pelo contrário, mesmo em 1734 já era uma passagem importante de ligação entre o litoral e as minas de Goiás e Mato Grosso.

\section{A MORADA DA FAZENDA SOBRADINHO I}

A morada térrea está situada em área plana, com declive na parte posterior, tendo o seu núcleo básico construído em formato retangular, com 13,60 metros de frente por 7,10 metros de frente aos fundos, perfazendo $96,56 \mathrm{~m}^{2}$. A área total da casa com acréscimo é de $212,83 \mathrm{~m}^{2}$. O embasamento é construído da combinatória de pedras e terra, sobre o qual se sustenta estrutura portante de madeira aparente, com paredes de vedação, externa e internamente em adobe. Ao redor de todas as paredes está nítida a presença do frechal que recebe o vigamento de madeira com armação de tesoura. A cobertura de múltiplos planos recebe telhas de barro. $\mathrm{O}$ piso é de assoalho de tábuas e de mezanela. As aberturas externas, portas e janelas, recebem vergas retas de madeira. As portas são de madeira e as janelas, retangulares, recebem externamente a armação da vidraça em guilhotina e internamente os escuros de uma folha e trancados com tramela. Parede de adobe e duas janelas internas treliçadas dividem o espaço social em dois. $\mathrm{O}$ sistema construtivo - gaiolas com paredes de vedação de adobe, o embasamento e cobertura - assim como os materiais empregados - madeira, pedras, areia e barro -, são originários e dependentes do meio. A exceção se dá pelas telhas industrializadas de barro e pelas janelas instaladas com vidro. Segundo suas funções atuais, os espaços internos estão assim distribuídos: (a) na porção fronteira, pelo espaço social ao centro, ladeado por um quarto, que se abre para a sala; (b) na faixa central, separados pelo espaço social, abrem-se mais dois dormitórios com janelas; (c) na parte de fundos, acrescida ao núcleo básico da morada, ampliou-se o espaço social e foram incorporados três quartos com janela, uma cozinha, dois banheiros, um depósito e uma varanda. A iluminação natural é oferecida através das janelas e pelas portas de frente e fundos. A morada recebe forro de madeira em toda a área do núcleo básico. Plasticamente nota-se a linearidade da planta retangular da morada. Nas fachadas, os cheios predominam sobre os vazios, com ausência de ornamentos (Figuras 7 e 8).

\section{A MORADA DA FAZENDA SOBRADINHO II}

A morada térrea está situada em área plana, com declive na parte posterior, tendo o seu núcleo básico planta praticamente quadrada, com 8,10 metros de frente por 8,50 metros de frente aos fundos, perfazendo $68,85 \mathrm{~m}^{2}$. A área total da casa com acréscimo é de $114,35 \mathrm{~m}^{2}$. O embasamento é construído da combinatória de pedras e terra, sobre o qual se 
Figura 7 - Planta baixa da morada da Fazenda Sobradinho I, destacados núcleo básico, prolongo e anexo. Fonte: BARBO, 2010.

Figura 8 - Fachada principal da Fazenda Sobradinho I. Foto: Acervo da PROAU-FAU UnB, 2008.
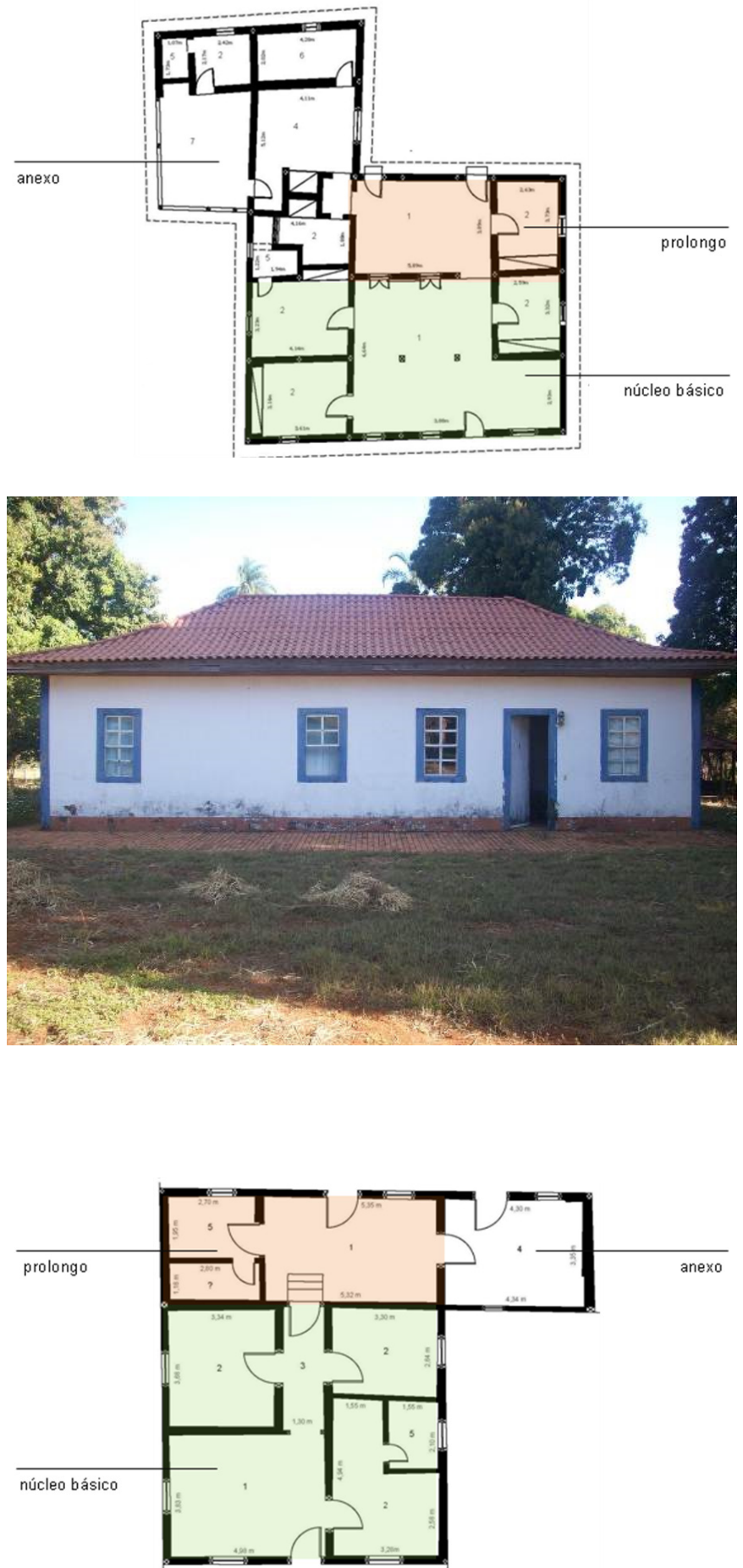

Figura 9 - Planta baixa da morada da Fazenda Sobradinho II, destacados núcleo básico, prolongo e anexo. Fonte: BARBO, 2010.

Figura 10 - Fachada principal da Fazenda Sobradinho II. Foto: Acervo da PROAU-FAU UnB, 2008.

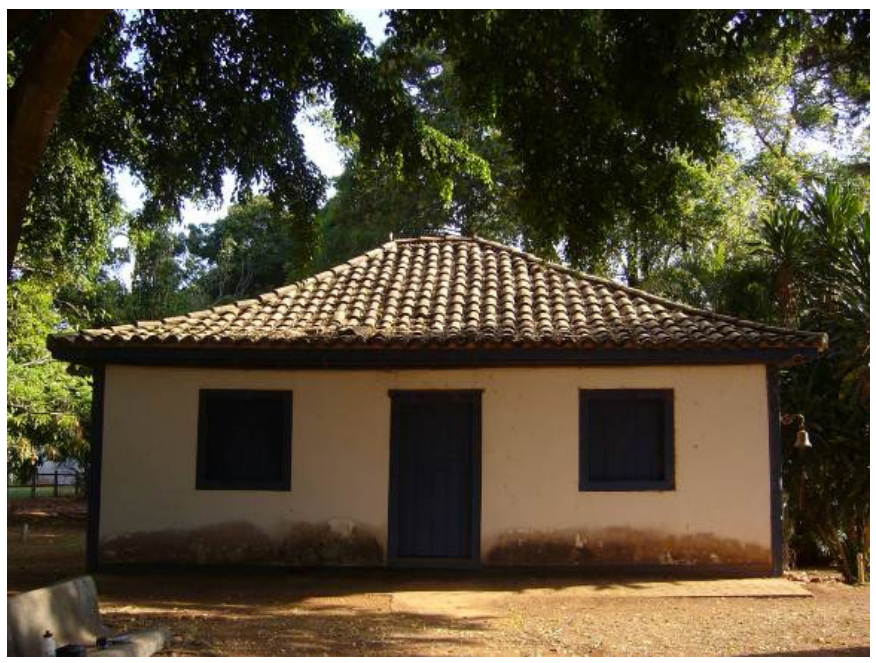


sustenta estrutura portante de madeira aparente, com paredes de vedação, externa e internamente em adobe. Ao redor de todas as paredes está nítida a presença do frechal que recebe o vigamento de madeira com armação de tesoura. A cobertura de quatro águas recebe telhas de capa e canal. O piso é de mezanela e de cimento queimado. As aberturas, portas e janelas, recebem vergas retas de madeira. As portas são de madeira e os vazios das janelas internamente são fechados pelos escuros e trancados com tramela. O sistema construtivo - gaiolas com paredes de vedação de adobe, o embasamento e cobertura - assim como os materiais empregados - madeira, pedras, areia e barro - são originários e dependentes do meio. Segundo suas funções atuais, os espaços internos estão assim distribuídos: (a) na porção fronteira, pelo espaço social de um lado e um quarto ${ }^{7}$ do outro que se abre para a sala, todos com janela; (b) na faixa central, separados por um corredor central, abrem-se mais dois dormitórios com janelas; (c) na parte de fundos, acrescida ao núcleo básico da morada, ampliou-se o espaço social e foram incorporados um banheiro, uma cozinha e outra sala. A iluminação natural é oferecida através das suas janelas e pelas portas de frente e fundos. $\mathrm{O}$ núcleo básico recebe forro de palha. $\mathrm{A}$ composição harmônica é principalmente sentida na superfície fronteiriça externa - duas janelas ladeando a porta central -, com os cheios predominando sobre os vazios e ausência de ornamentos. Plasticamente nota-se a linearidade e simetria decorrentes das aberturas quadradas das janelas e retangular da porta na fachada (Figuras. 9 e 10).

\section{GENERALIZANDO}

A pesquisa realizada de 2008 a 2010 permitiu constatar que uma série de características se repetem nas dez habitações estudadas. A morada rural encontrada é térrea, compacta na sua simplicidade, tem poucos cômodos. $\mathrm{O}$ diminuto porte das construções ocasionou frequentes reformas, que não tardaram a alterar, externa e internamente, as habitações, sem, contudo, as desfigurar nos seus elementos construtivos básicos, com exceção da Fazenda Desterro. O agenciamento espacial do corpo de oito moradas tem como partido predominante o retângulo, com plantas próximas ao quadrado; as outras duas - Gama e Sobradinho II - são quadradas. A cobertura predominante é a telha de barro com duas ou quatro águas, mas, em função do agenciamento dos prolongos, variam aos múltiplos planos. Apenas duas Curralinho e Desterro - têm telhas de fibrocimento. Todos os exemplares estudados foram construídos com materiais originários da própria região. As estruturas portantes são de madeira aparente e as paredes de adobe. A exceção é Saco Grande II, cujas paredes são de pau-a-pique. As portas e janelas de madeira, com apenas uma folha, sem ornato ou caixilhos eram fechadas com tramelas. As construções não possuíam forro ou estuque,
${ }^{7}$ Dentro deste quarto foi criado um banheiro. 
o comum foi o vigamento e as telhas ficarem à mostra, tendo em média, três metros de pé-direito. Apenas as casas do Gama e Sobradinho I possuíam forro de tábuas. Quanto às janelas, a Fazenda Sobradinho I é um caso à parte, apresentando diversos tipos: de apenas uma folha de madeira ou "escuro", de guilhotina com vidro e de treliça. Tudo indica que não fazem parte da construção inicial, mas sim frutos de reformas mais recentes. Os pisos nem sempre eram feitos de tábuas, usava-se regularmente a terra batida ou ainda mezanela. As fazendas Gama e Velha são as duas únicas que tiveram suas moradas restauradas.

Quanto à localização e ao ambiente natural as construções rurais inventariadas apresentam-se inseridas na paisagem local de forma muito parecida. O núcleo básico se encontra assentado em terreno praticamente plano, com o prolongo, quase sempre, em áreas com declive. Como regra geral, mostra-se a existência em seu entorno de grande número de árvores frutíferas e próximos a um curso d'água. Em algumas, ainda há resquícios de rego d'água, tirado de mina ou de curso de água, que chegava até a porta da casa. Os quintais, que podem ser entendidos como uma extensão do espaço domiciliar, eram lugares para a criação doméstica de animais, a pequena horta, as plantas aromáticas, ornamentais e medicinais e o pomar. Constituíam um recurso de importância fundamental para o abastecimento alimentar e apresentavam uma riqueza de cultivos considerável. As árvores frutíferas encontradas com maior frequência foram as mangueiras, jabuticabeiras, bananeiras, goiabeiras, jaqueiras e os jenipapos.

As moradias antigas do Planalto Central foram moradias enxutas, secas; água só na moringa ou no pote de barro. Perto da porta da cozinha, o telheiro para lavagens era isolado e, mais tarde, encostou-se à porta dos fundos (prolongo). Excetuando-se as Fazendas Sobradinho I e II, as moradas não ficavam à beira das antigas estradas, mas às margens de córregos ou regos d'água, entre outros motivos, para facilitar as lides domésticas.

O clima também foi importante agente que interferiu na organização das moradias. Em todos exemplares estudados, nas fachadas há grande predominância dos cheios sobre os vãos, para enfrentar a forte insolação da região. Observa-se que nenhuma das dez moradas apresentou, no seu núcleo básico, varanda ou alpendre.

Quanto à área, dos dez exemplares, nove tem seu núcleo básico com metragens que vão de 50 a $100 \mathrm{~m}^{2}$. Apenas a Saco Grande I apresenta núcleo básico com cerca de $35 \mathrm{~m}^{2}$. Depoimentos dos moradores informam que a casa original era construída mais próxima ao curso d'água e que devido a repetidas enchentes foi desmontada e remontada mais acima no terreno. Não temos informações suficientes para avaliar se foi obedecido o projeto da casa original.

Após análise detalhada da planta baixa das moradas e seu entorno imediato, foram registrados vinte e um pontos em comum em quase todas elas: 
1. casas térreas;

2. núcleos básicos com planta retangular, somados a acréscimos;

3. corpo principal em terreno plano e prolongo em declive;

4. agenciamento do espaço de cozinhar na parte posterior da planta;

5. circulação centralizada atravessando a edificação;

6. porta da frente diretamente conectada pela circulação centralizada a outra nos fundos;

7. espaço social na frente da casa e espaço de serviço nos fundos;

8. ausência de varandas ou alpendres no núcleo básico;

9. cobertura de 2 ou 4 águas, com telhas de barro;

10. estrutura do telhado em madeira, sem forro;

11. paredes internas de meia altura;

12. materiais originários da própria região;

13. fachadas com predominância de cheios sobre os vãos;

14. estrutura portante de madeira aparente (gaiola);

15. paredes de adobe sobre embasamento de pedra;

16. piso de tábuas, cimento queimado ou mezanela;

17. janelas e portas de madeira, de vergas retas;

18. ausência de ornamentos;

19. forma plástica linear e simétrica;

20. quintal com árvores frutíferas;

21. curso d'água próximo.
Constata-se, ainda, que as moradas

rurais são resultantes de apenas dois tipos de núcleo básico. As casas das fazendas Curralinho, Monjolo I, Saco Grande I e Sobradinho II têm núcleo básico constituído de duas faixas horizontais. As outras seis, Desterro, Gama, Monjolo II, Saco Grande II, Sobradinho I e Velha têm núcleo básico constituído de três faixas verticais (Quadro 1).

Em que pese a diferença de conservação entre elas, é muito próximo o aspecto ou consequência formal das moradas como produto de um programa de vida todo peculiar no isolamento do planalto. As moradas inventariadas preservam a maioria de suas características arquitetônicas, apesar das alterações inevitáveis ao longo dos anos - exemplares centenários, remanescentes da cultura agrária anterior à construção de Brasília.

Apesar da importância do seu passado, o território do Planalto Central, nos atuais limites do DF, a partir da implantação da Nova Capital teve sua história ofuscada pela história de Brasília. Nas palavras reveladoras de Sylvia Ficher (2000):

Arcaísmo e contemporaneidade se misturam em Brasília. E sua história continua sendo escrita no registro do mito, apresentada como ocupação primeira de um local virgem, apagados os traços de alguns séculos da história do Goyaz, agora aparentemente sem passado e sem tradições próprias, esquecidos aqueles que aqui viveram antes da sua construção. 


\begin{tabular}{|c|c|c|c|c|c|c|c|c|c|c|c|c|}
\hline FAZENDAS & $\begin{array}{c}\text { PLANTA BAIXA DO } \\
\text { NÚCLEO BÁSICO - } \\
\text { NB }\end{array}$ & $\begin{array}{c}\text { CARACTERÍS } \\
\text { TICAS DO } \\
\text { NúCLEO } \\
\text { BÁSICO } \\
\end{array}$ & PLANTA & $\begin{array}{c}\text { ÁREA } \\
\mathbf{m}^{2}\end{array}$ & COBERTURA & MATERIAIS & ESTRUTURA & PAREDES & PISO & JANELAS & PORTAS & OBS \\
\hline Faz. CURRALIN & & $\begin{array}{c}\text { Duas faixas } \\
\text { horizontais }\end{array}$ & $\begin{array}{l}\text { planta } \\
\text { retangular } \\
\text { com } \\
\text { acréscimo }\end{array}$ & $\begin{array}{c}\mathrm{NB}= \\
52,39 \\
\text { Total= } \\
81,25\end{array}$ & $\begin{array}{l}\text { cobertura de } \\
\text { duas águas / } \\
\text { telhas de } \\
\text { fibrocimento / } \\
\text { sem forro }\end{array}$ & $\begin{array}{l}\text { materiais } \\
\text { originários da } \\
\text { própria região }\end{array}$ & $\begin{array}{l}\text { estrutura } \\
\text { portante de } \\
\text { madeira } \\
\text { aparente }\end{array}$ & $\begin{array}{l}\text { paredes } \\
\text { com tijolos } \\
\text { de adobe }\end{array}$ & $\begin{array}{c}\text { piso de } \\
\text { tábuas e } \\
\text { de } \\
\text { cimento } \\
\text { queimado }\end{array}$ & $\begin{array}{c}\text { janelas } \\
\text { verticais de } \\
\text { madeira } \\
\text { com uma } \\
\text { folha de } \\
\text { escuro }\end{array}$ & $\begin{array}{l}\text { portas de } \\
\text { madeira } \\
\text { com uma } \\
\text { folha }\end{array}$ & $\begin{array}{c}\text { curso } \\
\text { d'água } \\
\text { próximo / } \\
\text { quintal com } \\
\text { pomar }\end{array}$ \\
\hline Faz. D & & $\begin{array}{c}\text { Três faixas } \\
\text { verticais }\end{array}$ & $\begin{array}{l}\text { planta } \\
\text { retangular } \\
\text { com } \\
\text { acréscimo }\end{array}$ & $\begin{array}{c}\mathrm{NB}= \\
84,53 \\
\text { Total= } \\
226,63\end{array}$ & $\begin{array}{l}\text { cobertura de } \\
\text { duas águas / } \\
\text { telhas de } \\
\text { fibrocimento / } \\
\text { forro de ripas } \\
\text { de madeira } \\
\text { (recente) }\end{array}$ & $\begin{array}{c}\text { parte dos } \\
\text { materiais } \\
\text { originários da } \\
\text { própria região }\end{array}$ & $\begin{array}{l}\text { estrutura de } \\
\text { madeira e de } \\
\text { concreto }\end{array}$ & $\begin{array}{l}\text { paredes de } \\
\text { tijolos } \\
\text { maciços e } \\
\text { de adobe }\end{array}$ & $\begin{array}{c}\text { piso de } \\
\text { cimento } \\
\text { queimado } \\
\text { e de } \\
\text { cerámica }\end{array}$ & $\begin{array}{c}\text { janelas com } \\
\text { vidro e } \\
\text { perfis de } \\
\text { ferro } \\
\text { do tipo } \\
\text { basculante } \\
\text { e de correr }\end{array}$ & $\begin{array}{l}\text { portas de } \\
\text { madeira } \\
\text { com uma } \\
\text { folha }\end{array}$ & $\begin{array}{c}\text { curso } \\
\text { d'água } \\
\text { próximo / } \\
\text { quintal com } \\
\text { pomar }\end{array}$ \\
\hline Faz. & & $\underset{\substack{\text { Três faixas } \\
\text { verticais }}}{\substack{1 \\
\mid}}$ & $\begin{array}{c}\text { planta } \\
\text { quadrada } \\
\text { com } \\
\text { acréscimo }\end{array}$ & $\begin{array}{c}N B= \\
100,00 \\
\text { Total }= \\
200,10\end{array}$ & $\begin{array}{c}\text { cobertura de } \\
\text { quatro águas } \\
\text { telha francesa } \\
\text { sem forro }\end{array}$ & $\begin{array}{c}\text { materiais } \\
\text { originários da } \\
\text { própria região }\end{array}$ & $\begin{array}{c}\text { estrutura } \\
\text { portante de } \\
\text { madeira } \\
\text { aparente }\end{array}$ & $\begin{array}{l}\text { paredes } \\
\text { com tijolos } \\
\text { de adobe }\end{array}$ & $\begin{array}{l}\text { piso de } \\
\text { tábuas e } \\
\text { de } \\
\text { cimento } \\
\text { queimado }\end{array}$ & $\begin{array}{c}\text { janelas } \\
\text { verticais de } \\
\text { madeira } \\
\text { com uma } \\
\text { folha e do } \\
\text { tipo } \\
\text { basculante }\end{array}$ & $\begin{array}{l}\text { portas de } \\
\text { madeira } \\
\text { com uma } \\
\text { folha }\end{array}$ & $\begin{array}{c}\text { curso } \\
\text { d'água } \\
\text { próximo / } \\
\text { quintal com } \\
\text { pomar / } \\
\text { edificação } \\
\text { restaurada }\end{array}$ \\
\hline Faz. 1 & & Duas faixas & $\begin{array}{l}\text { planta } \\
\text { retangular } \\
\text { com } \\
\text { acréscimo }\end{array}$ & $\begin{array}{l}\mathrm{NB}= \\
73,00 \\
\text { Total= } \\
137,08\end{array}$ & $\begin{array}{c}\text { cobertura de } \\
\text { quatro águas / } \\
\text { telhas de capa } \\
\text { e canal / } \\
\text { sem forro }\end{array}$ & $\begin{array}{c}\text { materiais } \\
\text { originários da } \\
\text { própria regiăo }\end{array}$ & $\begin{array}{l}\text { estrutura } \\
\text { portante de } \\
\text { madeira } \\
\text { aparente }\end{array}$ & $\begin{array}{l}\text { paredes } \\
\text { com tijolos } \\
\text { de adobe }\end{array}$ & $\begin{array}{l}\text { piso de } \\
\text { tábuas e } \\
\text { de } \\
\text { cimento } \\
\text { queimado }\end{array}$ & $\begin{array}{c}\text { aberturas } \\
\text { de madeira } \\
\text { com perfis } \\
\text { de ferro e } \\
\text { vidro } \\
\text { de correr e } \\
\text { basculante }\end{array}$ & $\begin{array}{l}\text { portas de } \\
\text { madeira } \\
\text { com uma } \\
\text { folha }\end{array}$ & $\begin{array}{c}\text { curso } \\
\text { d'água } \\
\text { próximo / } \\
\text { quintal com } \\
\text { pomar }\end{array}$ \\
\hline Faz. MONJOLO & & $\begin{array}{c}\text { Três faixas } \\
\text { verticais }\end{array}$ & $\begin{array}{l}\text { planta } \\
\text { retangular } \\
\text { com } \\
\text { acréscimo }\end{array}$ & $\begin{array}{c}\mathrm{NB}= \\
66,08 \\
\text { Total= } \\
133,07\end{array}$ & $\begin{array}{l}\text { cobertura de } \\
\text { múltiplos } \\
\text { planos } \\
\text { telhas de capa } \\
\text { e canal } \\
\text { sem forro }\end{array}$ & $\begin{array}{c}\text { materiais } \\
\text { originários da } \\
\text { própria região }\end{array}$ & $\begin{array}{l}\text { estrutura } \\
\text { portante de } \\
\text { madeira } \\
\text { aparente }\end{array}$ & $\begin{array}{c}\text { paredes } \\
\text { com tijolos } \\
\text { de adobe }\end{array}$ & $\begin{array}{c}\text { piso de } \\
\text { cimento } \\
\text { queimado }\end{array}$ & $\begin{array}{c}\text { janelas } \\
\text { verticais de } \\
\text { madeira } \\
\text { com uma } \\
\text { folha de } \\
\text { escuro }\end{array}$ & $\begin{array}{l}\text { portas de } \\
\text { madeira } \\
\text { com uma } \\
\text { folha }\end{array}$ & $\begin{array}{c}\text { curso } \\
\text { d'água } \\
\text { próximo / } \\
\text { quintal com } \\
\text { pomar }\end{array}$ \\
\hline Faz. SACO GR & & $\begin{array}{c}\text { Duas faixas } \\
\text { horizontais }\end{array}$ & $\begin{array}{l}\text { planta } \\
\text { retangular } \\
\text { com } \\
\text { acréscimo }\end{array}$ & $\begin{array}{c}\mathrm{NB}= \\
35,10 \\
\text { Total= } \\
133,36\end{array}$ & $\begin{array}{l}\text { cobertura de } \\
\text { múltiplos } \\
\text { planos / } \\
\text { telhas de capa } \\
\text { e canal / } \\
\text { sem forro }\end{array}$ & $\begin{array}{l}\text { materiais } \\
\text { originários da } \\
\text { própria região }\end{array}$ & $\begin{array}{c}\text { estrutura } \\
\text { portante de } \\
\text { madeira } \\
\text { aparente }\end{array}$ & $\begin{array}{l}\text { paredes } \\
\text { com tijolos } \\
\text { de adobe }\end{array}$ & \begin{tabular}{|c} 
piso de \\
cimento \\
queimado
\end{tabular} & $\begin{array}{c}\text { janelas } \\
\text { verticais de } \\
\text { madeira } \\
\text { com uma } \\
\text { folha de } \\
\text { escuro }\end{array}$ & $\begin{array}{l}\text { portas de } \\
\text { madeira } \\
\text { com uma } \\
\text { folha }\end{array}$ & $\begin{array}{c}\text { curso } \\
\text { d'água } \\
\text { próximo / } \\
\text { quintal com } \\
\text { pomar }\end{array}$ \\
\hline Faz. SACO GR & & $\begin{array}{l}\text { Três faixas } \\
\text { verticais }\end{array}$ & $\begin{array}{l}\text { planta } \\
\text { retangular } \\
\text { com } \\
\text { acréscimo }\end{array}$ & $\begin{array}{c}\mathrm{NB}= \\
50,35 \\
\text { Total= } \\
144,80\end{array}$ & $\begin{array}{c}\text { cobertura de } \\
\text { duas águas / } \\
\text { telhas de capa } \\
\text { e cana / } \\
\text { sem forro }\end{array}$ & $\begin{array}{c}\text { materiais } \\
\text { originários da } \\
\text { própria região }\end{array}$ & $\begin{array}{c}\text { estrutura } \\
\text { portante de } \\
\text { madeira } \\
\text { aparente }\end{array}$ & $\begin{array}{l}\text { paredes de } \\
\text { taipa-de- } \\
\text { mão ou } \\
\text { paa-pique }\end{array}$ & $\begin{array}{l}\text { piso de } \\
\text { cimento } \\
\text { queimado }\end{array}$ & $\begin{array}{l}\text { janelas } \\
\text { verticais de } \\
\text { madeira } \\
\text { com uma } \\
\text { folha de } \\
\text { escuro }\end{array}$ & $\begin{array}{l}\text { portas de } \\
\text { madeira } \\
\text { com uma } \\
\text { folha }\end{array}$ & $\begin{array}{c}\text { curso } \\
\text { d'água } \\
\text { próximo / } \\
\text { quintal com } \\
\text { pomar }\end{array}$ \\
\hline 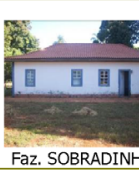 & & $\begin{array}{c}\text { Três faixas } \\
\text { verticais }\end{array}$ & $\begin{array}{l}\text { planta } \\
\text { retangular } \\
\text { com } \\
\text { acréscimo }\end{array}$ & $\begin{array}{c}\mathrm{NB}= \\
96,56 \\
\text { Total= } \\
212,83\end{array}$ & $\begin{array}{l}\text { cobertura de } \\
\text { múttiplos } \\
\text { planos / } \\
\text { telhas de barro/ } \\
\text { parte com forro } \\
\text { de madeira e } \\
\text { parte sem forro }\end{array}$ & $\begin{array}{l}\text { materiais } \\
\text { originários da } \\
\text { própria região }\end{array}$ & $\begin{array}{c}\text { estrutura } \\
\text { portante de } \\
\text { madeira } \\
\text { aparente }\end{array}$ & $\begin{array}{l}\text { paredes } \\
\text { com tijolos } \\
\text { de adobe }\end{array}$ & $\begin{array}{l}\text { piso de } \\
\text { tábuas e } \\
\text { de } \\
\text { mezanela }\end{array}$ & $\begin{array}{c}\text { janelas } \\
\text { verticais de } \\
\text { madeira } \\
\text { com uma } \\
\text { folha, } \\
\text { guilhotina } \\
\text { com vidro e } \\
\text { treliçadas }\end{array}$ & $\begin{array}{l}\text { portas de } \\
\text { madeira } \\
\text { com uma } \\
\text { folha }\end{array}$ & $\begin{array}{c}\text { curso } \\
\text { d'água } \\
\text { próximo / } \\
\text { quintal com } \\
\text { pomar }\end{array}$ \\
\hline Faz. SOBRADINH & & $\begin{array}{c}\text { Duas faixas } \\
\text { horizontais }\end{array}$ & $\begin{array}{c}\text { planta } \\
\text { quadrada } \\
\text { com } \\
\text { acréscimo }\end{array}$ & $\begin{array}{l}\mathrm{NB}= \\
68,85 \\
\text { Total= } \\
114,35\end{array}$ & $\begin{array}{c}\text { cobertura de } \\
\text { quatro águas / } \\
\text { telhas de capa } \\
\text { e canal / } \\
\text { forro de palha } \\
\text { (recente) }\end{array}$ & $\begin{array}{c}\text { materiais } \\
\text { originários da } \\
\text { própria regiăo }\end{array}$ & $\begin{array}{l}\text { estrutura } \\
\text { portante de } \\
\text { madeira } \\
\text { aparente }\end{array}$ & $\begin{array}{l}\text { paredes } \\
\text { com tijolos } \\
\text { de adobe }\end{array}$ & $\begin{array}{c}\text { piso de } \\
\text { mezanela } \\
\text { e de } \\
\text { cimento } \\
\text { queimado }\end{array}$ & $\begin{array}{c}\text { janelas } \\
\text { quadradas } \\
\text { de madeira } \\
\text { com uma } \\
\text { folha de } \\
\text { escuro }\end{array}$ & $\begin{array}{l}\text { portas de } \\
\text { madeira } \\
\text { com uma } \\
\text { folha }\end{array}$ & $\begin{array}{c}\text { curso } \\
\text { d'água } \\
\text { próximo / } \\
\text { quintal com } \\
\text { pomar }\end{array}$ \\
\hline Faz. VELHA & & Três faixas & $\begin{array}{l}\text { planta } \\
\text { retangular } \\
\text { com } \\
\text { acréscimo }\end{array}$ & $\begin{array}{l}\mathrm{NB}= \\
77,97 \\
\text { Total= } \\
147,15\end{array}$ & $\begin{array}{c}\text { cobertura de } \\
\text { quatro águas / } \\
\text { telhas de capa } \\
\text { e canal / } \\
\text { sem forro }\end{array}$ & $\begin{array}{l}\text { materiais } \\
\text { originários da } \\
\text { própria região }\end{array}$ & $\begin{array}{c}\text { estrutura } \\
\text { portante de } \\
\text { madeira } \\
\text { aparente }\end{array}$ & $\begin{array}{l}\text { paredes } \\
\text { com tijolos } \\
\text { de adobe }\end{array}$ & $\begin{array}{c}\text { piso de } \\
\text { tábuas e } \\
\text { de } \\
\text { cimento } \\
\text { queimado }\end{array}$ & $\begin{array}{c}\text { janelas } \\
\text { verticais de } \\
\text { madeira } \\
\text { com uma } \\
\text { folha de } \\
\text { escuro / } \\
\text { edificação } \\
\text { restaurada }\end{array}$ & $\begin{array}{l}\text { portas de } \\
\text { madeira } \\
\text { com uma } \\
\text { folha }\end{array}$ & $\begin{array}{c}\text { curso } \\
\text { d'água } \\
\text { próximo / } \\
\text { quintal com } \\
\text { pomar }\end{array}$ \\
\hline
\end{tabular}




\section{REFERÊNCIAS BIBLIOGRÁFICAS}

BARBO, L. C. A arquitetura rural das estradas coloniais do Planalto Central. In: IV Simpósio Internacional de História: Cultura e Identidades, 2009, Goiânia (GO). Anais IV Simpósio Internacional de História: Cultura e Identidades. Goiânia: UFG/ANPUH-GO, 2009. v.1. p.1-1.

BARBO, L. C. Preexistências de Brasília. Reconstruir o território para construir a memória. Dissertação (Mestrado em Arquitetura e Urbanismo). UnB, Brasília, 2010.

BRUNO, E. S. (Coord.). As selvas e o pantanal. São Paulo: Cultrix, 1959.

CARDOZO, J. Um tipo de casa rural do Distrito Federal e Estado do Rio. In: MACEDO, D.; SOBREIRA, F. (Orgs.). Forma estática - forma estética: ensaios de Joaquim Cardozo sobre arquitetura e engenharia. Brasília: Câmara dos Deputados, 2009.

COELHO, G. N.; VALVA, M. d'A. Patrimônio cultural edificado. Goiânia: EdUCG, 2001.

CORONA, E.; LEMOS, C. Dicionário da arquitetura brasileira. São Paulo: Romano Guerra, 2017.2. ed. (Coleção RG facsímile, 3).

COSTA, L. Fazenda da Babilônia ou São Joaquim. Pirenópolis - GO. In: PESSÔA, J. (Org.). Lucio Costa: documentos de trabalho. Rio de Janeiro: IPHAN, 2004.

COSTA, L. Registro de uma vivência. São Paulo: Editora 34: Edições Sesc São Paulo, 2018.

DIOGO, J. C. Roteiro de viagem de José da Costa Diogo e João Barbosa, sobre a derrota do rio São Francisco pelo rio Urucuya até às Minas de Goiás. [post. 1734, Novembro]. In: Arquivo Histórico Ultramarino - AHU - Goiás. Projeto Resgate. AHU_ACL_ CU_008, Cx. 1, D. 8.

FARIAS, D. D. Terras no Distrito Federal: experiências com desapropriações em Goiás: 1955-1958. Dissertação (Mestrado). Departamento de História, Universidade de Brasília, 2006.

FICHER, S. Brasílias. Revista Projeto Design, n 242, p. 48-52, abr. 2000.

FREITAS, L.; SILVA, N. Antigas fazendas do Planalto Central. Ciências Humanas em Revista, Goiânia, n.6, p.113-130, jul-dez, 1995.

IBGE. Censo experimental de Brasília. Rio de Janeiro: 1959.

JAYME, J. Cinco vultos meia-pontenses. Instituto Genealógico Brasileiro: 1943.

LEMOS, C. A. C. A casa brasileira. São Paulo: Contexto, 1989. (Coleção Repensando a história).

OLIVEIRA, A. M. V. Fazendas Goianas: a casa como universo de fronteira. Goiânia: UFG, 2010.

OLIVEIRA, A. M. V. Uma ponte para o mundo goiano do século XIX: um estudo da casa meia-pontense. Goiânia: Agência Goiana de Cultura Pedro Ludovico Teixeira, 2001.

PACHECO, A. M. Primórdios de Brasília. Revista do Instituto Histórico e Geográfico de Goiás, Goiânia, n.4, p.83-175, dez, 1975.

SCHLEE, A. R. O clima e a arquitetura brasileira. Revista Ciência e Ambiente, v. 22, p. 19-34, jan./jun. 2001. 
SCHLEE, A. R.; FERREIRA, O.; VIEIRA JR., W. J.; BARBO, L. C. Preservar e Intervir em Brasília. O caso das antigas fazendas do Distrito Federal. In: ZEIN, Ruth Verde (Org.). Projeto como investigação: Antologia. São Paulo: Alter Market, 2009, v. 1, p. - .

VAZ, M. D. A. C.; ZÁRATE, M. H. V. A casa goiana: documentação arquitetônica. Goiânia: Ed. da UCG, 2003.

Lenora Barbo - Doutora em Arquitetura e Urbanismo pela Universidade de Brasília. Grupo de Pesquisa CNPq Arquitetura e Urbanismo da Região de Brasília, Faculdade de Arquitetura e Urbanismo - UnB, linha de pesquisa Preexistências brasilienses. lenorabarbo@gmail.com.

Andrey Rosenthal Schlee - Professor Titular da Faculdade de Arquitetura e Urbanismo da Universidade de Brasília; Diretor de Patrimônio Material e Fiscalização do Instituto do Patrimônio Histórico e Artístico Nacional (2012 a 2019). andreyrosenthal@gmail.com. 